\title{
Factors Affecting Pharmacist's Performance Based on Motivation Theory: A Systematic Review
}

\author{
Dona Muin $^{1,2}$, Susi Ari Kristina ${ }^{3}$, Yayi Suryo Prabandari ${ }^{4} \&$ Satibi $^{3}$ \\ ${ }^{1}$ Doctoral Program in Pharmaceutical Science, Faculty of Pharmacy, Universitas Gadjah Mada, Yogyakarta, \\ Indonesia \\ ${ }^{2}$ Department of Pharmacy, Health Ministry Polytechnic, Jambi, Indonesia \\ ${ }^{3}$ Department of Pharmaceutics, Faculty of Pharmacy, Universitas Gadjah Mada, Yogyakarta, Indonesia \\ ${ }^{4}$ Department of Health Behavior, Environment Health \& Social Medicine, Faculty of Medicine, Nursing, and \\ Public Health, Universitas Gadjah Mada, Yogyakarta, Indonesia \\ Correspondence: Dona Muin, Doctoral Program in Pharmaceutical Science, Faculty of Pharmacy, Universitas \\ Gadjah Mada, Yogyakarta, Indonesia; Department of Pharmacy, Health Ministry Polytechnic, Jambi, Indonesia. \\ Tel: 81-27-290-9100. E-mail: donamuin@yahoo.com
}

Received: October 28, 2018 Accepted: January 22, 2019 Online Published: January 30, 2019

doi:10.5539/gjhs.v11n3p13 URL: https://doi.org/10.5539/gjhs.v11n3p13

\begin{abstract}
Objective: Determine factors that affect the performance of pharmacist based on motivation theory.

Method: A systematic review was conducted to explore that affect factors an employee's performance, especially a pharmacist. Electronic databases used to identify relevant studies to the affecting factors such performance were Science Direct, PUBMED, UGM Library (Dissertation) and Google Scholar. The search terms used are "pharmacist performance", "performance-affecting factors for pharmacist", "pharmacist performance optimization", and "performance motivation". This study was limited to English and Indonesian language only and publication years from 2000 to 2016. Electronic search database found 50 articles while only six studies meet the eligibility criteria to serve as the basis for determining the performance of the pharmacist.
\end{abstract}

Results: Pharmacist performance was influenced by five factors: organization and environment, social order, resources owned, pharmacist characteristics, and regulation. These five variables are considered by the Alderfer ERG theory of Existence, Relatedness, and Growth.

Conclusion: Performance for pharmacists should be emphasized with systemic supports for pharmaceutical practice changes to succeed on a wide scale and devote to producing a good performance.

Keywords: pharmacist, performance, motivation

\section{Introduction}

The important role of a pharmacist for society must be a concern to support the quality of patient life. A pharmacist must have a good performance to do the task, function, responsibility, and role to society well. Hence, evaluation of the performance of a pharmacist in doing the pharmaceutical works and in identifying the factors regarding the pharmacist performance is critical. This assessment is valuable to evaluate to what extent a pharmacist can work by the task, function, responsibility, and role to the society (Mangkunegara, 2005).

Performance can be detected through the motivation of the workers with the quality of service, efficiency, and justice; all of which are directly mediated by the workers' willingness to apply themselves in their tasks. For a pharmacist, performance refers to the work achievement for him/herself as a comparison between the work and work standards applied by the organization. It is found that the performance is related to three core factors: psychological (perception, attitude, personality, learning, and motivation); organizational (resources, leadership, appreciation, structure, work division) and individual (competence, skill, background, and individual characteristics) (Robbins, 2014). This is viewed in line with the motivation theories, one of which is the Alderfer's ERG theory. Alderfer stated that human is motivated by three categories of core needs: existence (E), relatedness (R) and growth $(\mathrm{G})$ (Wilcove, 1978). The basic needs of the human are psychologically supported by the needs to socialize and needs to grow and work (Arnolds \& Boshoff, 2002). To understand what motivates the health 
practitioners including pharmacist in their work, it is deemed important to explore what factors affecting the pharmacist performance. By so doing, the organization can have an empirical basis to decide to improve the pharmacist performance in improving the quality of people health. This research was designed to observe the factors of pharmacist's performance and attempted to correlate the compatibility factor determining the pharmacist performance using the motivation from of Alderfer's ERG theory. This theory was selected for being viewed as a valid hierarchy from the need aspect. Also, it has been seen to have created more supports from the contemporary researchers in the work situation as long as it is still related to motivation (Wilcove, 1978). One of the main strengths of Alderfer's theory is that this theory specifically is focused on the nature of work. Theoretically, the particular reference is made to provide a benefit related to the association need and the growth of co-workers and employers to have job satisfaction in the workplace (Arnolds \& Boshoff, 2002).

\section{Method}

The systematic review was conducted to identify all relevant studies.

\subsection{Study Identification}

The systematic review was conducted to identify the relevant studies purposely to answer the objective of writing this article regarding the factors affecting the performance of the pharmacist based on the theory of motivation.

Four media of electronic data (PUBMED, Science Direct), Library of UGM (Dissertation of UGM) and Google Cendekia were firstly searched in December 2016. The search terms used are summarized in Table 1. The additional articles were identified through the reference tracking.

Table 1 . Search terms used to identify the relevant studies

\begin{tabular}{lll}
\hline No & Database & Search Term \\
\hline 1 & Science Direct (2000-2016) & pharmacist performance \\
2 & PUBMED (2000-2016) & $\begin{array}{l}\text { pharmacist performance, performance affecting } \\
\text { factors for pharmacist } \\
\text { pharmacist performance optimization }\end{array}$ \\
3 & UGM Library (Dissertation) (2000-2016) & performance motivation \\
\hline
\end{tabular}

\subsection{Data Extraction}

The data were independently extracted by a study using the form of data extraction including the research details to find out the factors related to the pharmacist performance and any drawbacks in improving the performance

\section{Result}

A systematic review was arranged to find out what factors affect the performance of the pharmacist based upon the theory of motivation. To do so, the researcher conducted an extraction of the article by firstly determining the inclusion criteria through the title, extraction, and full text. Subsequently, the data independently were extracted by the researcher using the form of data extraction including the detail of the research showing the factors related to the performance and efforts to improve the performance of a pharmacist.

\subsection{Screening and Assessment of Selected Studies}

The study assessment by reviewers is a working group as shown in the following Figure 1. 
50 Articles (6 Articles from PubMed,

27 Articles from Science Direct, five articles from UGM Library

(Dissertation), and 12 Articles from Google Scholar

Screening

50 Articles were screened by title, abstract, and full text

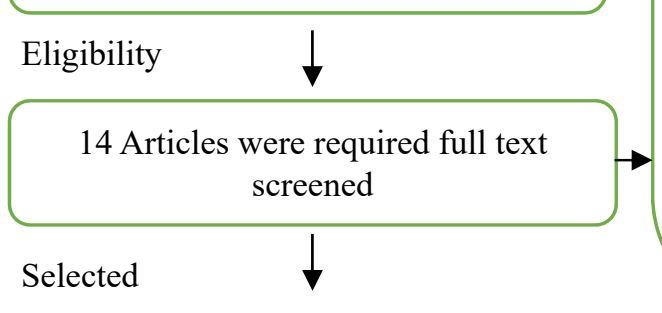

\section{Articles excluded}

44 articles were excluded:

- Two articles on the concentration of health organization

- Five articles on the test of the effect of environmental factors - out of the motivation factor.

- Fifteen articles on the research of the interaction of pharmacist and patients.

- Nine articles only to research by using salary as the only performance parameter.

- Eight articles used the instruments and samples not relevant to the worker performance (i.e., top management)

- 11 articles to study the knowledge of pharmacist about the disease
Eight articles on the organization and finance with the doubled concentration concentration
Six articles included elected in the review

Figure 1. PRISMA Diagram

The results of the search are presented in Figure 1. The basis of the electronic data found 50 articles (6 articles from PubMed, 27 articles from Science Direct, five articles from Library of UGM (Dissertation), and 12 articles from the title of Google Scholar). Of 50 abstracts identified, 44 articles were eliminated, and six articles were included in the review.

\subsection{Characteristics of Studies}

Some articles show that the performance of a worker is the factor of the achievement of an organization in reaching the target either in quality or in quantity. Hence, finding out what factors affecting the performance of an employee is deemed critical to be the basis in deciding top management to improve the performance.

In this article, the author attempts to make the discussion narrower by tracking the performance of a pharmacist with an expectation that it can be the basis of the organization consideration towards the pharmacist.

The studies reviewed were from Canada, Chezc, London, and Indonesia. Many types of research have been used to develop the literature-based questionnaires, and most of the studies have used the group discussion focused on exploring the pharmacist perception. Some of these researches did some experiments and validity of questionnaires. However, not all have explained the validity phases in detail. Table 2 presents five used types of research doing validity and questionnaires reading. Another research did not mention the validity phases. Subsequently, the researcher searched for the determining factors through the description of the research characteristics and the search on the factors affecting the pharmacist performance. 
Table 2. Characteristics of the studies

\begin{tabular}{|c|c|c|c|c|c|c|}
\hline No & Author, /Year & $\begin{array}{l}\text { City } \\
\text { /Country }\end{array}$ & $\begin{array}{l}\text { Research } \\
\text { Design }\end{array}$ & Indicator & Variable & Result \\
\hline 1 & $\begin{array}{l}\text { (Schaftheutle, } \\
\text { Seston, \& } \\
\text { Hassell, 2011) }\end{array}$ & $\begin{array}{l}\text { Manchester } \\
\text { UK }\end{array}$ & $\begin{array}{l}\text { Systematic } \\
\text { review }\end{array}$ & $\begin{array}{ll}- & \text { Age } \\
- & \text { Ethnicity } \\
- & \text { Sex } \\
- & \text { Work } \\
& \text { experience } \\
- & \text { Training/ } \\
& \text { seminar } \\
- & \text { Finance } \\
- & \text { Workload }\end{array}$ & $\begin{array}{ll}\text { - } & \text { Organization } \\
\text { and } \\
\text { environment }\end{array}$ & $\begin{array}{l}\text { Mental and Physical } \\
\text { factors (health and } \\
\text { demography of } \\
\text { pharmacist) education }\end{array}$ \\
\hline 2 & $\begin{array}{l}\text { (Chandler, } \\
\text { Chonya, Mtei, } \\
\text { Reyburn, \& } \\
\text { Whitty, 2009) }\end{array}$ & $\begin{array}{l}\text { London, } \\
\text { Great } \\
\text { Britain }\end{array}$ & $\begin{array}{l}\text { Mixed-method } \\
\text { study }\end{array}$ & $\begin{array}{ll}\text { - } & \text { Social status } \\
\text { - } & \text { Finance } \\
\text { - } & \text { Remuneration } \\
& \text { Salary/ } \\
\text { Incentives } \\
\text { - } \quad \text { Work } \\
\text { environment } \\
\text { - } \quad \text { Work relation } \\
\text { - } \quad \text { Policy } \\
\text { - } \quad \text { Workload } \\
\text { - } \quad \text { Work } \\
\text { satisfaction } \\
\text { Loyalty } \\
\text { - } & \text { Organization } \\
\text { Commitment } \\
\text { - } \quad \text { Work security } \\
\text { Justice } \\
\text { organization } \\
\text { Managerial } \\
\text { support } \\
\text { Resource } \\
\text { availability } \\
\text { The position of } \\
\text { social and } \\
\text { family }\end{array}$ & $\begin{array}{ll}- & \begin{array}{l}\text { Organization } \\
\text { and } \\
\text { environment }\end{array} \\
- & \text { Social status } \\
- & \begin{array}{l}\text { Pharmacist } \\
\text { characteristic }\end{array} \\
\mathrm{s} \\
- & \text { Resources } \\
- & \text { Regulation }\end{array}$ & $\begin{array}{l}\text { Motivator of non-salary } \\
\text { only will affect the } \\
\text { fulfillment of the } \\
\text { requirement } \\
\text { satisfying salary }\end{array}$ \\
\hline 3 & $\begin{array}{l}\text { (Hendrartini, } \\
\text { 2011) }\end{array}$ & $\begin{array}{l}\text { Yogyakarta } \\
\text { Indonesia }\end{array}$ & $\begin{array}{l}\text { Cross-sectional } \\
\text { survey }\end{array}$ & $\begin{array}{ll}\text { - } & \begin{array}{l}\text { Able to } \\
\text { cooperate }\end{array} \\
\text { - } & \text { Policy } \\
& \text { Commitment } \\
\text { - } & \begin{array}{l}\text { Allowances and } \\
\text { incentive }\end{array} \\
\text { - } & \text { Relation with } \\
\text { partner or work } \\
\text { relation }\end{array}$ & $\begin{array}{ll}\text { - } & \text { Organization } \\
\text { and } \\
\text { environment } \\
\text { - } & \text { Regulation }\end{array}$ & $\begin{array}{l}\text { The main variables } \\
\text { affecting the } \\
\text { performance of doctors } \\
\text { including attitude, } \\
\text { followed by knowledge, } \\
\text { contract duration, and } \\
\text { work satisfaction }\end{array}$ \\
\hline
\end{tabular}




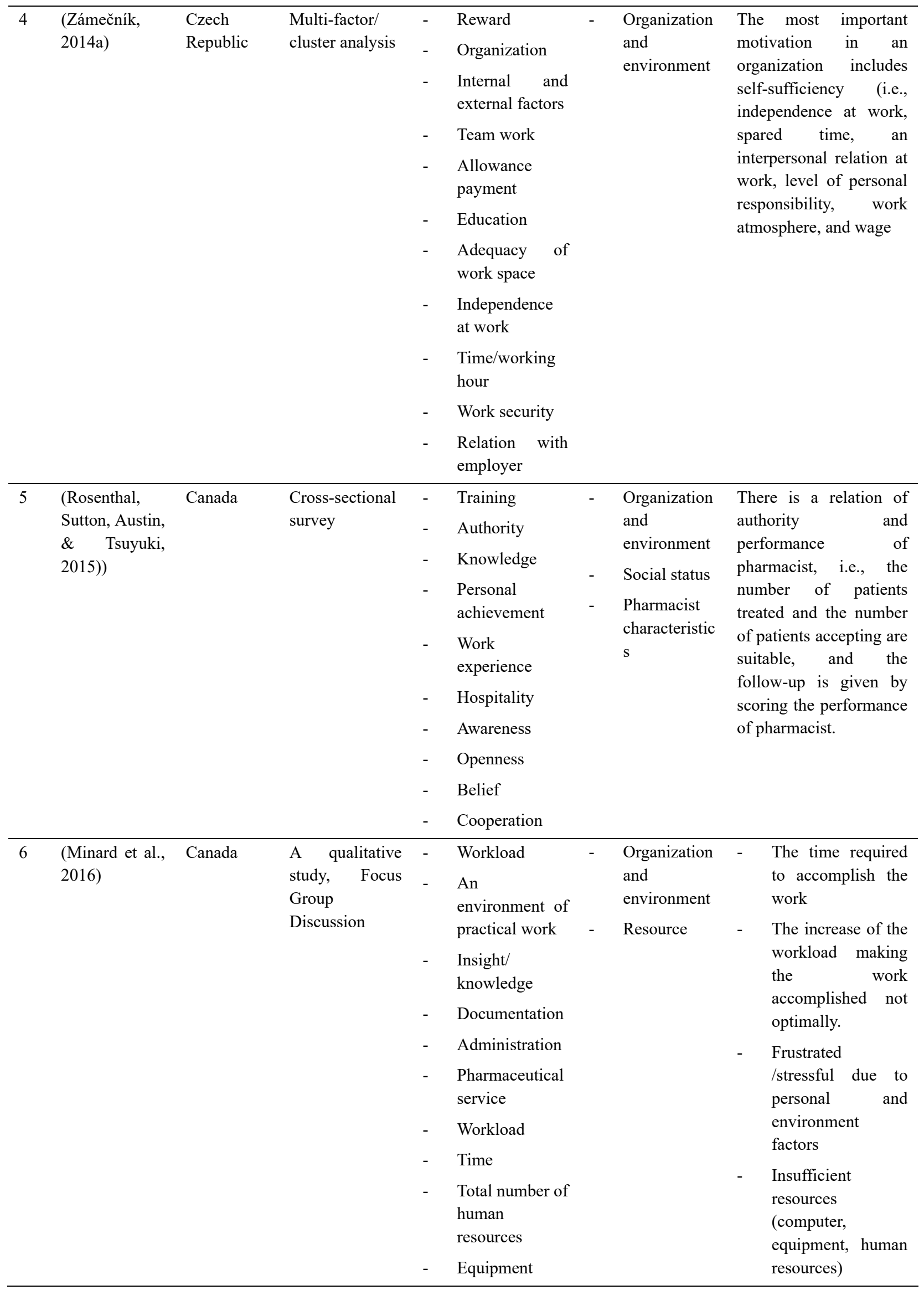




\subsection{Factors Related to Pharmacists' Performance}

\subsubsection{Organization and Environment}

Some evidence shows that the performance of health professionals from minority ethnicity is highly affected by factors related to the work spirit and it is assumed that those working in an organization without any work spirit (Chilingerian, 1995), the organization and environment can give the output of pharmacist performance with a different way (Schaftheutle et al., 2011). The study of Schaftheutle (Schaftheutle et al., 2011) found some evidence showing that the pharmacists have some overload works, work experience, stress factors related to the performance problem - particularly on the mistakes frequently made by the pharmacists. Also, Chandler (Chandler et al., 2009) discussed that work quality is highly related to the work, environment, peer relationships, workload, job satisfaction, loyalty, organizational commitment, job security, organizational justice, and managerial support (Chandler et al., 2009).

Focus group discussions conducted by Minard (Minard et al., 2016) explored the perception of obstructions and pharmacist facilitators. The research revealed that the obstructions to the clinical pharmacy implementation included the time required to complete work, the continually increasing number of jobs, making the task unable to complete optimally, being frustrated/stressful due to personal factors and outside parties. The pharmacists are identified to have the increase of workload as a barrier to doing activities; as a consequence, they feel to have no sufficient time to do their work properly (Awaisu \& Alsalimy, 2015). Meanwhile, a motivation for someone in the work world has been discussed in the study conducted by Zamecnic (2014) and Franco (Franco, Bennett, \& Kanfer, 2002). Zámečník (Zámečník, 2014a) used a questionnaire containing many factors related to performance and motivational factors. Zámečník (Zámečník, 2014a) mentioned about 27 motivational factors. From the article, it is found that the most important motivators included self-sufficiency in the workplace, free time, and relations among employees, level of personal responsibility and atmosphere in the workplace, and wage/salary levels (Zámečník, 2014a). Motivation workers will be guided by health sector reform influencing the organization, reporting structure, human resource management, accountability, and types of interaction with clients and society. (Rosenthal, Tsao, Tsuyuki, \& Marra, 2016).

In the study of Hendrartini (Hendrartini, 2011), the main variables affecting the performance of a pharmacist included the attitude, knowledge, the length of the contract, and job satisfaction in the organization. Then, the study was supported by the research by Rosenthal (Rosenthal et al., 2015) that analyzed the relation between personality and performance of the pharmacist showing that the score of the performance was affected by the relation of work partners, attitude of the pharmacist, job satisfaction and the number of patients given the service.

\subsubsection{Social Status}

Community environment around the pharmacist has the status and role on each bringing an effect on the way of the pharmacist to do their duties and responsibilities. This study showed that several factors identified about other health professions could also affect the pharmacist performance. Health workers such as doctors, nurses, midwives, and other health workers have some different job orientations and goals. To make it clearer, pharmacists can work in several pharmaceutical sectors, but, of course, it requires an expertise in accepting and the ability to link collaboration with other health professions (Bajis, Chaar, Penm, \& Moles, 2016). Chandler in the article also discussed a social status taking apart in the spirit in improving the quality of work or performance (Chandler et al., 2009).

\subsubsection{Resources}

Low performance has been associated with motivation. For low-level motivation, one of the aspects is the human resource crisis in which today it needs to be well understood to achieve the improvements in the performance of public health services (Hongoro \& McPake, 2004). The article of Chandler revealed that the human resource crisis occurred in pharmacist work needs to be understood to improve the performance of public health services (Hongoro \& McPake, 2004). Supported by focus group discussions conducted by Minard (Minard et al., 2016), it also revealed that the obstacles in doing pharmaceutical work were also influenced by inadequate resources (computers, equipment, and human resources). The lack of human resources has made the pharmacists to experience the increasing workload as a barrier to do the activities. Therefore, pharmacists feel to have no sufficient time to do their work well (Awaisu \& Alsalimy, 2015).

\subsubsection{Pharmacist' Characteristics}

A study conducted by Schaftheutle (Schaftheutle et al., 2011) showed evidence about gender and race bringing out various performance problems. The pharmacist performance is also affected by several factors, including personal characteristics such as age, and stress (Kreitner \& Kinicki, 2012). The domains identified in the study of 
Schaftheutle (Schaftheutle et al., 2011) included demography (age, sex, race), psychological values, and education (Kreitner \& Kinicki, 2012). In the article, Rosenthal mentioned that hospitality, openness, awareness, self-confidence, cooperation, and analysis are closely related to pharmacist performance (Rosenthal et al., 2016).

\subsubsection{Regulation}

Regulations used by governments or organizations as the guidelines for the work implementation of the pharmacist are related to payment methods, pharmacist authorities, and social relations. Chandler (Chandler et al., 2009) Revealed that the higher salaries are related to internal motivation. Motivation is closely related to high qualifications and additional salaries received by the pharmacists. Thus, the salary requirements are very clearly for motivation. These results are in line with the research hypothesis of Chandler stating that that non-salary motivators will only affect if the salary requirements are satisfactory, which in turn leads to improved performance. This study also showed that the performance of clinical and non-clinical personnel including pharmacists is influenced by many interrelated things not only by the work environment, peer relations, workload, job satisfaction, loyalty, organizational commitment, job security, organizational justice, managerial support, but also by salaries and incentives. Study on obedience in policy closely related to the performance of a health worker is be found in the study by (Hendrartini, 2011) on the payment system for primary doctors in health insurance programs in Indonesia. This study aimed to describe the effects of variables on the doctor's performance who pay capitation. In this study, the percentage of capitation income did not have a direct effect on the doctor performance, but through attitudes as an intermediary variable.

Policymakers have little empirical evidence about the effect of policy on performance (Chandler et al., 2009). For many clinical and non-clinical personnel, a little work environment and salary could eliminate assumptions that must be changed in health policy, which, according to policy makers, are voluntary - working without thinking of rewards.

\subsection{Alderfer's ERG Motivation Theory Related to Factors Affecting Pharmacist Performance}

In this research, we associated motivation theory with factors affecting the pharmacist performance. Alderfer's ERG motivation theory explained that the motivation of a worker could be determined by 3 things: Existence (E) as a basic human need to support life and physical and psychological security, Relatedness $(\mathrm{R})$ as the need to live to socialize and interact with others, and Growth $(\mathrm{G})$ as the need to develop and work. These three ERG factors influence, complement, and strengthen to each other (Hongoro \& McPake, 2004).

Motivation in ERG theory explains that an organization must maintain good communication and relation either among employees or between employer and employees; it must create a healthy and safe environment for harmonious interaction among employees by following the principles of mutual respect and tolerance; recognition, group security, and reputation improvement to manage social relations needs; job satisfaction and self-confidence of employees are maintained by concerning with the needs of social relationships: opportunities for all organization members are equally provided to give opportunities for employees to grow and develop. If the need for growth is hindered, employees will be demotivated and seek satisfaction at a lower level (Bajis et al., 2016).

The relation of the ERG Alderfer theory and five factors of main variables that have been obtained as the factors affecting the performance of the pharmacist can be correlated in each part of Existence (E), Relatedness (R), and Growth $(\mathrm{G})$ with all contributors in the main variables of factors affecting the pharmacist performance.

\subsubsection{Existence}

Existence (E) refers to the basic need of a pharmacist arising as the lowest level of need with the indicators covering six main variables such as indicator of finance ((Schaftheutle et al., 2011; Chandler et al., 2009; Zámečník, 2014b), work security (Chandler et al., 2009), adequacy of workspace, independence at workplace, work hours (Zámečník, 2014a), availability of human resources, availability of equipment resources, age (Chandler et al., 2009; Hendrartini, 2011), ethnic, gender, (Chandler et al., 2009; Rosenthal et al., 2015), work experience, excessive work, job satisfaction, and loyalty (Chandler et al., 2009).

\subsubsection{Relatedness}

Relatedness (R) refers to social needs related to the relation between a pharmacist and other people and the environment. This indicator emerges in the form of relation with the superior, work environment, work relationship, organization commitment (Chandler et al., 2009; Zámečník, 2014a), justice in organization, management support, organization commitment (Chandler et al., 2009; Hendrartini, 2011), relation (Minard et al., 2016), relationships with work partner, social level, and social position, family position (Chandler et al., 2009; Rosenthal et al., 2015). 


\subsubsection{Growth}

Growth $(\mathrm{G})$ refers to the needs of a pharmacist to have creativity, and to grow regarding ability and competence, moving forward, and grow through sustainable learning. In this review, the indicators shown came from the indicators of training/seminar, a practice of environment, education/knowledge (Schaftheutle et al., 2011; Zámečník, 2014a; Rosenthal et al., 2015; Minard et al., 2016).

\section{Discussion}

Factors that influence the pharmacist performance include five main variables containing some indicators obtained in 5 types of related research. The variables included organization and environment (finance, training/seminars, workplace environment, peer relations, organizational commitment, job security, organizational justice, management support, organizational commitment, peer relations, adequacy of workspace, freedom/workplace authority, working hours, job security, relationship with superiors, practice, training) (Robbins, 2014; Wilcove, 1978; Arnolds \& Boshoff, 2002; Schaftheutle et al., 2011; Chandler et al., 2009; Hendrartini, 2011); social order (social status, position in society, position in family) (Schaftheutle et al., 2011; Zámečník, 2014a); resources (availability of resources, number of workers, equipment); Characteristics of pharmacists (age, ethnicity, gender, work experience, workload, job satisfaction, loyalty, able to work together, education, knowledge, personality achievement, work experience, hospitality, awareness, openness, confidence, workload, knowledge (Arnolds \& Boshoff, 2002; Chandler et al., 2009; Zámečník, 2014a); and regulations (payroll, finance, salary, benefits, incentives, awards, time/working hours, policies, documentation, administration) (Arnolds \& Boshoff, 2002; Hendrartini, 2011; Zámečník, 2014a).

Relations of the co-worker, employer, work environment and living environment are highlighted as the indicators of the emergence of the first major variable called Organizations and Environment. Therefore, Organization and Environment are described as a part of the work environment and outside the work environment around the pharmacist including the pharmacist organizations that share the goals related to pharmaceutical work affecting the quality of work life in the hospital with patients, co-workers, and employer. Meanwhile, social status, government perception, family, patients, co-workers and the community towards the pharmacist profession have created the second variable. Social Status is described as the community perception around pharmacist interaction by their respective status and roles that influence the duties and responsibilities of the pharmacist. For the third variable, resources are described as the potential values owned by hospitals to support the work quality of pharmacists, physically or non-physically. Other factors highlighted in the third variable were the number of workers (human resources), facilities, and equipment used by pharmacists when doing the pharmaceutical work. The fourth variable arises from the indicator of pharmacist demography (including ethnicity, age, and sex), experience, insight, and psychological characteristics. In general, the fourth variable, namely Pharmacist Characteristics, is described as a pharmacist's lifestyle both in personality and in health so that behavior becomes more consistent and easy to be noted including demography and health factors. The decisions of the government and organization where the pharmacist works at include salary, remuneration, incentives, and working hours as listed in the fifth variable indicator, namely Regulation as the guidelines in the implementation of pharmacist work in hospitals including payment methods, pharmacist authorities, organizational policies, and government regulations.

By the description, it then can be concluded that there is a compatibility of the factors affecting the pharmacist performance with the contents of the Alderfer's ERG motivation theory. Thus, it is found that the pharmacist performance is influenced by five main variables: organization and environment; social order; resource; pharmacist characteristics; and regulation, which is consistent with Alderfer's ERG motivation theory.

\section{Conclusion}

Finally, it can be concluded that to encourage a better understanding of performance related to this motivation, it must be understood that the contribution of a pharmacist not only depends on the performance of the pharmacist itself and the organization in which they are guided in but also depends on the government support in the professional role of pharmacists in supporting the improvement of the community health. A good understanding of the contribution of a pharmacist's work and a good relationship will greatly affect the quality of the pharmacist's work. Knowing the factors that influence the pharmacist performance is then expected to be the basis for decision making in organizational management where pharmacists take refuge to improve the quality of pharmacist work. The factors affecting this performance cannot be separated from the relevance of motivation based on the factors of Existence, Relatedness, and Growth (Alderfer's ERG) a pharmacist must possess.

\section{Ethic Approval and Consent to Participate}

Since only to official public data were used in this study, neither institutional board approval, not informed consent 
was required.

\section{Acknowledgment}

The author is very grateful for the compilation of this systematic review. This systematic review is supported by the Center for Quality Improvement of Human Resources for Health from the Republic of Indonesia Ministry of Health (BPPSDM Health).

\section{Authors' Contribution}

DM conceptualized and coordinated the study and drafted the manuscript. SAK, S, YSP aided in the study design, ensuring that all the elements of the protocol were reflected in the manuscript, contributed to the design, reviewed the contributions, and reviewed the content of the protocol of the manuscript. All authors read and approved the final version.

\section{Competing Interests Statement}

The authors declare that there are no competing or potential conflicts of interest.

\section{References}

Arnolds, C. A., \& Boshoff, C. (2002). Compensation, esteem valence and job performance: an empirical assessment of Alderfer's ERG theory. The International Journal of Human Resource Management, 13(4), 697-719. https://doi.org/10.1080/09585190210125868

Awaisu, A., \& Alsalimy, N. (2015). Pharmacists' involvement in and attitudes toward pharmacy practice research: A systematic review of the literature. Research in Social and Administrative Pharmacy, 11(6), 725-748. https://doi.org/10.1016/j.sapharm.2014.12.008

Bajis, D., Chaar, B., Penm, J., \& Moles, R. (2016). Competency-based pharmacy education in the Eastern Mediterranean Region-A scoping review. Currents in Pharmacy Teaching and Learning, 8(3), 401-428. https://doi.org/10.1016/j.cptl.2016.02.003

Chandler, C. I. R., Chonya, S., Mtei, F., Reyburn, H., \& Whitty, C. J. M. (2009). Motivation, money, and respect: A mixed-method study of Tanzanian non-physician clinicians. Social Science \& Medicine, 68(11), 2078-2088. https://doi.org/10.1016/j.socscimed.2009.03.007

Chilingerian, J. A. (1995). Evaluating physician efficiency in hospitals: A multivariate analysis of best practices. Productivity Analysis: Parametric and Non-Parametric Applications, 80(3), 548-574. https://doi.org/10.1016/0377-2217(94)00137-2

Franco, L. M., Bennett, S., \& Kanfer, R. (2002). Health sector reform and public sector health worker motivation: a conceptual framework. Social Science \& Medicine, 54(8), 1255-1266. https://doi.org/10.1016/S0277-9536(01)00094-6

Hendrartini. (2011). Doctor Performance Model With Capitation Payment Program in Health Insurance. Gadjah Mada University Library, Yogyakarta, Indonesia, Dissertation. Retrieved from http://lib.ugm.ac.id/ind/?page_id=248

Hongoro, C., \& McPake, B. (2004). How to Bridge the Gap in Human Resources for Health. The Lancet, 364(9443), 1451-1456. https://doi.org/10.1016/S0140-6736(04)17229-2

Kreitner, R., \& Kinicki, A. (2012). Organizational Behavior. McGraw-Hill Education.

Mangkunegara, A. A. A. P. (2005). Evaluation of HR Performance. Surakarta, Indonesia: Tiga Serangkai.

Minard, L., V., Deal, H., Harrison, M. E., Toombs, K., Neville, H., \& Meade, A. (2016). Pharmacists' Perceptions of the Barriers and Facilitators to the Implementation of Clinical Pharmacy Key Performance Indicators. PLOS One. Retrieved from http://journals.plos.org/plosone/article?id=10.1371/journal.pone.0152903

Robbins, S. (2014). Behavior And Organizational Management, edisi 7, jilid 1 (Vol. 7). Jakarta, Indonesia: Erlangga.

Rosenthal, M., Sutton, J., Austin, Z., \& Tsuyuki, R. T. (2015). Relationship between personality traits and pharmacist performance in a pharmacy practice research trial. Canadian Pharmacists Journal / Revue Des Pharmaciens Du Canada, 148(4), 209-216. https://doi.org/10.1177/1715163515586846

Rosenthal, M., Tsao, N. W., Tsuyuki, R. T., \& Marra, C. A. (2016). Identifying relationships between the professional culture of pharmacy, pharmacists' personality traits, and the provision of advanced pharmacy services. Research in Social and Administrative Pharmacy, 12(1), 56-67. 
https://doi.org/10.1016/j.sapharm.2015.05.003

Schaftheutle, E. I., Seston, E. M., \& Hassell, K. (2011). Factor Influencing Pharmacist Performance, A review of the peer-review literature. Health Policy, 102 (2011), 178-192. https://doi.org/0.1016/j.healthpol.2011.06.004

Wilcove, G. L. (1978). The ERG model: Expansion and application to Navy personnel. Journal of Vocational Behavior, 13(3), 305-316. https://doi.org/10.1016/0001-8791(78)90057-X

Zámečník, R. (2014b). The Measurement of Employee Motivation by Using Multi-factor Statistical Analysis. 2nd World Conference on Business, Economics, and Management, 109(Supplement C), 851-857. https://doi.org/10.1016/j.sbspro.2013.12.553

\section{Copyrights}

Copyright for this article is retained by the author(s), with first publication rights granted to the journal.

This is an open-access article distributed under the terms and conditions of the Creative Commons Attribution license (http://creativecommons.org/licenses/by/4.0/). 